\title{
Effect of nitrogen sources for spikelet sterility and yield of boro rice varieties
}

\begin{abstract}
This research work was carried out to determine the suitable nitrogen source for increasing the grain yield by reducing spikelets sterility in boro rice. The experiment comprised four nitrogen sources such as no nitrogen (T0), BRRI recommended dose of prilled urea (T1), Govt. approved dose of mixed NPK (T2) and BARC recommended dose of USG (T3), and four varieties viz. BRRI dhan29 (V1), BRRI dhan58 (V2), BADC SL8H (V3) and Heera (V4). The application of USG showed the highest grain yield $(8.6 \mathrm{t} / \mathrm{ha})$ and the lowest percentage of spikelet sterility than any other nitrogen sources. All the studied characters except leaf area, dry matter weight and harvest index varied significantly among the varieties. This is mainly attributable to the highest number of filled grains (98.8/panicle) with markedly lower level of spikelet sterility (7.3\%) was found from BRRI dhan29. The combination of the USG application and BRRI dhan29 had the higher performance in terms of producing the highest grain yield by significant reduction of spikelet sterility among the interaction effects.
\end{abstract}

Keywords: oryza sativa, n-sources, varieties, sterility, yield
Volume 5 Issue 5 - 2016

\author{
Sheikh Salamat Ullah,' Ruhul Amin AKM, \\ Tuhin Suvro Roy,' MSH Mandal, ${ }^{2}$ Mehraj $\mathrm{H}^{3}$ \\ 'Department of Agronomy, Sher-e-Bangla Agricultural University, \\ Dhaka \\ ${ }^{2}$ Hiroshima University, Japan \\ ${ }^{3}$ The United Graduate School of Agricultural Science, Ehime \\ University, Japan
}

Correspondence: Mehraj H,The United Graduate School of Agricultural Science, Ehime University, Ehime 790-8556, Japan, Email hmehraj02@yahoo.com

Received: July 02, 2016 | Published: December 22, 2016
Abbreviations: SAU, sher-e-bangla agricultural university; BRRI, Bangladesh rice research institute; BAD, Bangladesh agricultural development corporation; BARC, Bangladesh agricultural research council; AEZ, agro ecological zones; USG, urea super granule, DAT, days after transplanting

\section{Introduction}

Rice yield can be increased in many ways such as developing new high yielding varieties or adopting proper agronomic management to the existing varieties. Proper fertilization is an important management practice to increase rice yield. Proper fertilization can markedly increase the yield and improve the quality of rice. ${ }^{1}$ Nitrogenous fertilizer has immense effect on rice yield throughout the positive influence on the production of effective tillers. ${ }^{2}$ Nitrogen not only enhances the yield of rice but also reduces the spikelet sterility. Nitrogen is required in adequate amount at early, at mid tillering and panicle initiation stage for better grain development. ${ }^{3,4}$ The soil nitrogen status of Bangladesh is also very low due to warm climate as well as extensive cultivation practices without addition of manures. The nitrogen efficiency, especially of urea fertilizer, is very low in rice cultivation. Nitrogen losses ranged from $2.82-5.07 \%$ in rice field. ${ }^{5}$ The use of USG and Mixed fertilizer has often been advocated to minimize nitrogen losses because organic manures act as a great source of plant nutrients, especially of N, P, K and S, and also prevents leaching loss of the nutrients. USG @ $120 \mathrm{~kg} \mathrm{~N} \mathrm{ha}^{-1}$ was the best in producing the yield and yield attributes of rice. ${ }^{5}$ Prilled urea also plays a vital role in improving physical, chemical and biological properties of the soil and ultimately enhances crop production. Application of heavy nitrogen increases tillering as well as spikelet number per plant thus reduces the number of engorged pollen grains per anther and leading into increased spikelet sterility. ${ }^{6}$ This study was undertaken to evaluate the response of different varieties with the application of different nitrogen sources for obtaining optimum yield by reducing spikelet sterility of boro rice.

\section{Material and methods}

Experimental period: The experiment was conducted at the Agronomy Farm of SAU, Dhaka, Bangladesh during the Boro season of December 2012 to May 2013.

Treatments and design: Four different nitrogen source viz. No nitrogen $\left(T_{0}\right)$, BRRI recommended dose of prilled urea $\left(T_{1}\right)$, recommended dose of mixed NPK $\left(\mathrm{T}_{2}\right)$, BARC recommended dose $(66 \mathrm{~kg} \mathrm{~N} / \mathrm{ha})$ of USG $\left(\mathrm{T}_{3}\right)$ and four varieties viz. Heera $\left(\mathrm{V}_{1}\right)$, BADC SL8H $\left(\mathrm{V}_{2}\right)$, BRRI dhan58 $\left(\mathrm{V}_{3}\right)$ and BRRI dhan29 $\left(\mathrm{V}_{4}\right)$ were used in the experiment. The BRRI recommended dose of urea in Madhupur tract (AEZ 28) for hybrid and inbred varieties are 150 and $120 \mathrm{~kg} \mathrm{ha}^{-1}$ respectively. BARC recommended dose of USG is $66 \mathrm{~kg} \mathrm{ha}^{-1}$. Mixed NPK dose was $30-35 \mathrm{~kg} \mathrm{ha}^{-1}$. The experiment was laid out following split plot design with three replications where main plot was for nitrogen source and subplot was for variety. The size of the unit plot was $4 \mathrm{mX} 2.5 \mathrm{~m}$ with a space between replications $1.0 \mathrm{~m}$ and unit plots $0.50 \mathrm{~m}$.

Planting Material: High yielding variety BRR1 dhan29 and BRRI dhan 58 and hybrid variety BADC SL $8 \mathrm{H}$ and Heera of boro season were used as test crop. BRRI dhan 29 and BRRI dhan 58 were developed by BRRI, Gazipur, Bangladesh. The grains of BRRI dhan 29 and BRRI dhan58 are medium-slender with light-golden husks. BADC SL8H was introduced in BADC and Heera was introduced by Supreme Seed Company Ltd. from China. The grains of BADC SL8H are golden, slightly slender and comparatively larger in size. The grains of Heera are medium, thick with light golden husks.

Collection and preparation of initial soil sample: The initial soil samples were collected before land preparation from a $0-15 \mathrm{~cm}$ soil depth by means of an auger from different location covering the whole experimental plot and mixed thoroughly to make a composite sample. After collection of soil samples, the plant roots, leaves etc. were picked up and removed. Then the sample was air-dried and sieved through a sieve and stored in a clean plastic container for physical and chemical analysis. 
Fertilization: TSP, MP, gypsum and zinc sulphate were applied at the rate of $148-178-100-15 \mathrm{~kg} \mathrm{ha}^{-1}$, respectively except in the $\mathrm{T}_{2}$ treatment plot. ${ }^{7}$ There were two rates of urea for $T_{1}$ treatment plot such as $260 \mathrm{~kg}$ $\mathrm{ha}^{-1}$ for inbred and $325 \mathrm{~kg} \mathrm{ha}^{-1}$ for hybrid rice. Full dose of TSP, MP, gypsum, zinc sulphate and cow dung $\left(10 \mathrm{tha}^{-1}\right)$ were applied as basal dose at final land preparation of individual plots. Urea was applied to $\mathrm{T}_{1}$ treatment plot in three equal splits on 15, 30 and 55 DAT for BRRI dhan 29 and BRRI dhan 58 and in case of hybrid varieties, the splits were 0,21 and 42 DAT, respectively.

Uprooting of seedlings: Seedlings of 40 for BRRI dhan 29 and BRRI dhan 58 while 30 days old hybrid varieties, respectively were uprooted from the nursery beds carefully.

Transplanting: Seedlings were transplanted on December 25, 2012 in the well-puddled experimental plots. Spacing was given $25 \mathrm{~cm} x 15 \mathrm{~cm}$ for BRRI dhan 29 and BRRI dhan 58 as well as $20 \mathrm{cmx} 15 \mathrm{~cm}$ for hybrid varieties. Two seedlings for BRRI dhan 29 and BRRI dhan 58 and one seedling for hybrid varieties were transplanted hill-1.

Gap filling: Seedlings of some hills died off and these were replaced by gap filling after one week of transplanting with seedlings from the same source.

Weeding: Manual weeding was done for three times during at 16 DAT, 31 DAT and 56 DAT followed by first, second and third top dressing of urea.

Irrigation and drainage: Irrigation was done by alternate wetting and drying from transplanting to maximum tillering stage. From panicle initiation (PI) to hard dough stage, a thin layer of water (2$3 \mathrm{~cm}$ ) was kept on the plots. Water was removed from the plots during ripening stage.

Plant protection measures: Plants were infested with rice stem borer and leaf hopper to some extent which was successfully controlled by applying three times of Diazinon on 14 and 25 March, 2013 and one times of Ripcord on 02 April 2013.

Harvesting and processing: The crop of each plot was harvested separately on different dates at full maturity when $80 \%$ of the grains become golden yellow in color. Hills from the central $4 \mathrm{~m}^{2}$ area of each plot were harvested for collecting data on crop yield. The harvested crop of each plot was bundled separately, tagged properly and brought to the clean threshing floor. The crops were threshed by pedal thresher and then grains were cleaned. The grain and straw weights for each plot were recorded after proper sun drying and then converted into ton hectare-1. The grain yield was adjusted at 14\% moisture level.

Recording of data: Data were collected on the following parameters - plant height, number of tillers, number of effective tillers, number of non-effective tillers, number of filled grains, number of unfilled grains, spikelet sterility, spikelet sterility at the top, middle and bottom portion of panicle, 1000-grains weight, grain yield, straw yield, biological yield, harvest Index.

The percentage of sterility was calculated by following formula

Sterility $(\%)=($ Number of sterile spikelet per panicle $\div$ number of total spikelet per panicle)X100

From the sample hills, each panicle was divided into three equal parts by eye estimation. The apical, middle and lower parts were termed as top, middle and bottom portion of panicle, respectively.
Percentage of sterility for each portion was calculated using following formulae:

1. Sterility at top portion $(\%)=($ Number of sterile spikelet at top portion of a panicle $\div$ number of total spikelet of a whole panicle) $\mathrm{X} 100$

2. Sterility at mid portion $(\%)=($ Number of sterile spikelet at mid portion of a panicle $\div$ number of total spikelet of a whole panicle) $\mathrm{X} 100$

3. Sterility at bottom portion $(\%)=($ Number of sterile spikelet at bottom portion of a panicle $\div$ number of total spikelet of a whole panicle)X100

1000-grain weight: One thousand clean dried (at 14\% moisture level) grains from the seed stock of each plot were counted separately and weighed.

Grain and straw yield: Grain and straw obtained from the central $4 \mathrm{~m}^{2}$ areas of each plot were sun dried, cleaned, weighed separately and finally converted into t/ha. Grains yield were measured by adjusting moisture level at $14 \%$

Biological yield: Grain yield and straw yield were together regarded as biological yield i.e., Biological yield $(\mathrm{t} / \mathrm{ha})=$ Grain yield $(\mathrm{t} / \mathrm{ha})+$ Straw yield $(\mathrm{t} / \mathrm{ha})$

Harvest index: It was calculated with the following formula:

Harvest Index $(\%)=($ Grain yield $\div$ Biological yield $) \mathrm{X} 100$

Statistical analysis: Data were analyzed following the analysis of variance (ANOVA) technique and the mean differences were adjudged at $5 \%$ level of probability using DMRT with a computer operated program named MSTAT-C. ${ }^{8}$

\section{Results and discussion}

\section{Growth characters}

Plant height: Effect of nitrogen dose and varieties for plant height showed in Figure 1. Tallest plant was recorded from $T_{3}(97.7 \mathrm{~cm}$ at harvest), $\mathrm{V}_{4}$ (96.8 at harvest) and $\mathrm{T}_{3} \mathrm{~V}_{4}(100.2 \mathrm{~cm}$ at harvest) whereas shortest from $\mathrm{T}_{0}(86.6 \mathrm{~cm}$ at harvest $), \mathrm{V}_{1}(87.0 \mathrm{~cm}$ at harvest $)$ and $\mathrm{T}_{0} \mathrm{~V}_{1}$ $(80.5 \mathrm{~cm}$ at harvest) at different DAT (Figure 1). Interaction of nitrogen sources and variety showed an increasing trend with advances of growth period in respect of plant height (Figure 1).

The rate of increase was higher in early growth stages (25-85 DAT) then increasing rate was much slower up to 105 DAT. Meena et al., ${ }^{9}$ Sahrawat et al., ${ }^{10}$ and Thakur ${ }^{11}$ were observed higher plant height with the higher doses of nitrogen. Tallest plant was found from. Plant height differed significantly among rice varieties. ${ }^{12-15}$

Leaf number, leaf area, and dry matter weight: Number of leaves varied significantly among the nitrogen sources, varieties and their combinations. The maximum number of leaves was found from $\mathrm{T}_{3}$ (142.4/hill), $\mathrm{V}_{4}(123.1 /$ hill $)$ and $\mathrm{T}_{3} \mathrm{~V}_{4}(157.6 /$ hill $)$ whereas minimum from $\mathrm{T}_{0}(85.6 / \mathrm{hill}), \mathrm{V}_{2}(94.0 / \mathrm{hill})$ and $\mathrm{T}_{0} \mathrm{~V}_{2}(68.8 /$ hill) (Figure 2). Significant variation was not found for the nitrogen sources, varieties but varied among the combination of those treatments. However, the maximum leaf area was observed from $\mathrm{T}_{3}\left(28.3 \mathrm{~cm}^{2}\right), \mathrm{V}_{3}\left(24.8 \mathrm{~cm}^{2}\right)$ and $\mathrm{T}_{3} \mathrm{~V}_{3}\left(30.6 \mathrm{~cm}^{2}\right)$ while minimum from $\mathrm{T}_{0}\left(20.3 \mathrm{~cm}^{2}\right), \mathrm{V}_{2}\left(23.8 \mathrm{~cm}^{2}\right)$ 
and $\mathrm{T}_{0} \mathrm{~V}_{2}\left(19.3 \mathrm{~cm}^{2}\right)$ (Figure 3). The maximum dry matter was found for $\mathrm{T}_{3}(42.0 \mathrm{~g} / \mathrm{hill}), \mathrm{V}_{4}(41.5 \mathrm{G} / \mathrm{hill})$ and $\mathrm{T}_{3} \mathrm{~V}_{4}(44.0 \mathrm{~g} / \mathrm{hill})$ whereas minimum from $\mathrm{T}_{1}(35.8 /$ hill $), \mathrm{V}_{1}(37.0 /$ hill $) \mathrm{T}_{1} \mathrm{~V}_{1}(33.2 /$ hill $)$ at 105 DAT (Figure 4).

\section{Yield components of boro rice}

Effective tillers: Significant variation was found for number of effective tiller among the nitrogen sources, varieties and those combinations. The highest number of the effective tiller was found for $\mathrm{T}_{3}(15.8 / \mathrm{hill}), \mathrm{V}_{4}(14.3 / \mathrm{hill})$ and $\mathrm{T}_{3} \mathrm{~V}_{4}(16.9 / \mathrm{hill})$ whereas lowest from $\mathrm{T}_{0}(9.3 /$ hill $), \mathrm{V}_{1}(12.2 /$ hill $)$ and $\mathrm{T}_{0} \mathrm{~V}_{1}(8.6 /$ hill) (Table 1$)$. Increasing levels of nitrogen increased the number of effective. ${ }^{28}$ These findings collaborate with those reported by BINA, ${ }^{16}$ Om et al., ${ }^{17}$ and Bhowmick et al., ${ }^{18}$ who stated that effective tillers/hill was varied with variety.

Non-effective tillers: The number of non-effective tiller was varied significantly for nitrogen sources and combinations but not varied due to the variation of variety. The maximum number of non-effective tiller was found for $\mathrm{T}_{0}(1.5 /$ hill $)$ and $\mathrm{T}_{0} \mathrm{~V}_{2}(1.7 /$ hill $)$ while minimum for $\mathrm{T}_{3}(0.6 /$ hill $)$ and $\mathrm{T}_{3} \mathrm{~V}_{2}(05 /$ hill $)$ (Table 1$)$.

Filled grains: Nitrogen sources, varieties and combinations showed significant variation on production of filled grains. Maximum number of filled grain was for the $\mathrm{T}_{3}$ (102.1/panicle), $\mathrm{V}_{4}$ (98.8/panicle) and $\mathrm{T}_{3} \mathrm{~V}_{4}$ (115.1/panicle) whereas minimum for $\mathrm{T}_{0}(69.5 /$ panicle $), \mathrm{V}_{2}$ (82.1/panicle) and $\mathrm{T}_{0} \mathrm{~V}_{2}(63.2 /$ panicle) (Table 1$)$.

Unfilled grains: Nitrogen sources, varieties and combinations of these treatments had significant influence on unfilled grains panicle (Table 1). Lowest number of unfilled grain was obtained from $\mathrm{T}_{3}$ (6.7/panicle), $\mathrm{V}_{1}$ (7.5/panicle) and $\mathrm{T}_{3} \mathrm{~V}_{1}$ (5.0/panicle) while highest $\mathrm{T}_{0}$ (14.7/panicle), $\mathrm{V}_{2}$ (13.7/panicle) and $\mathrm{T}_{0} \mathrm{~V}_{4}$ (19.2/panicle) (Table 1). The interaction result showed that interaction of BRRI dhan 29 with all the nitrogen doses produced higher number of unfilled grains/ panicle (ranged 5.0-19.7). The result was supported by BRRI ${ }^{19}$ that no nitrogen produced the highest number of unfilled grains/panicle in boro season.

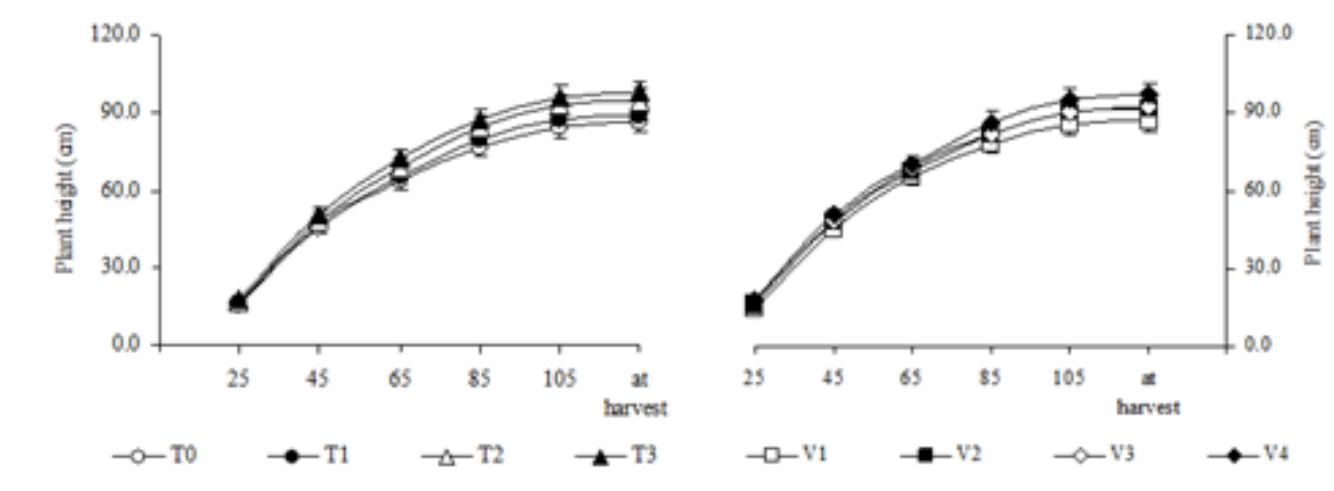

Days after transplanting (DAT).

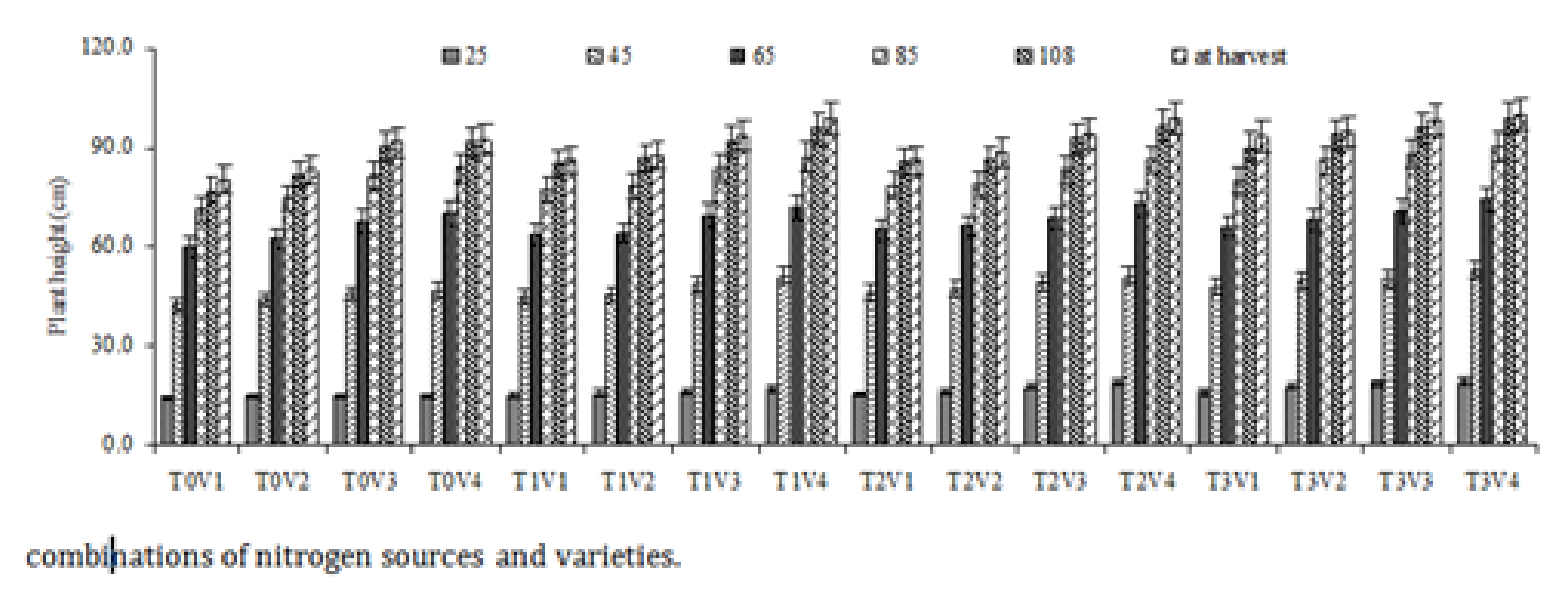

Figure 1 Results for rice plant height due to different nitrogen sources and

ii. varieties

Here, $\mathrm{V}_{1}=$ Heera, $\mathrm{V}_{2}=\mathrm{SL} 8 \mathrm{H}, \mathrm{V}_{3}=\mathrm{BRRI}$ dhan58, $\mathrm{V}_{4}=\mathrm{BRRI}$ dhan29, and $\mathrm{T}_{0}=$ Control, $\mathrm{T}_{1}=$ Prilled Urea, $\mathrm{T}_{2}=$ Mixed Urea, $\mathrm{T}_{3}=$ USG 

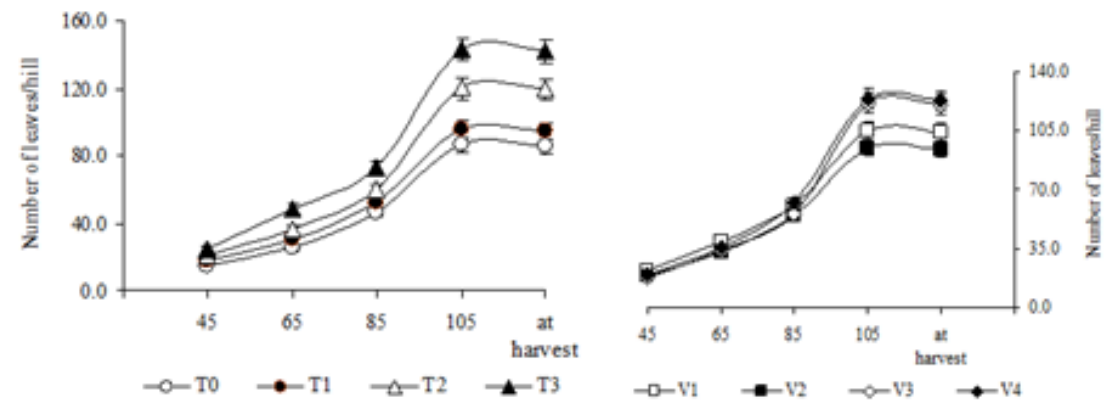

Days after transplanting (DAT).

Figure 2 Effect of different

i. nitrogen sources and

ii. varieties

iii. combinations for number of leaves of rice

Here, $\mathrm{V}_{1}=$ Heera, $\mathrm{V}_{2}=\mathrm{SL} 8 \mathrm{H}, \mathrm{V}_{3}=\mathrm{BRRI}$ dhan58, $\mathrm{V}_{4}=\mathrm{BRRI}$ dhan 29 , and $\mathrm{T}_{0}=$ Control, $\mathrm{T}_{1}=$ Prilled Urea, $\mathrm{T}_{2}=$ Mixed Urea, $\mathrm{T}_{3}=$ USG
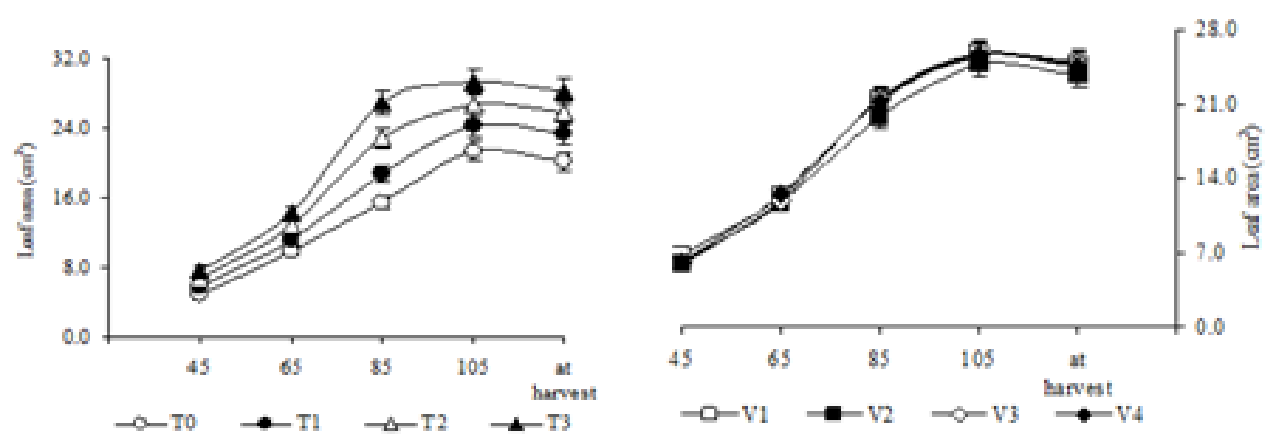

Days after transplanting (DAT).

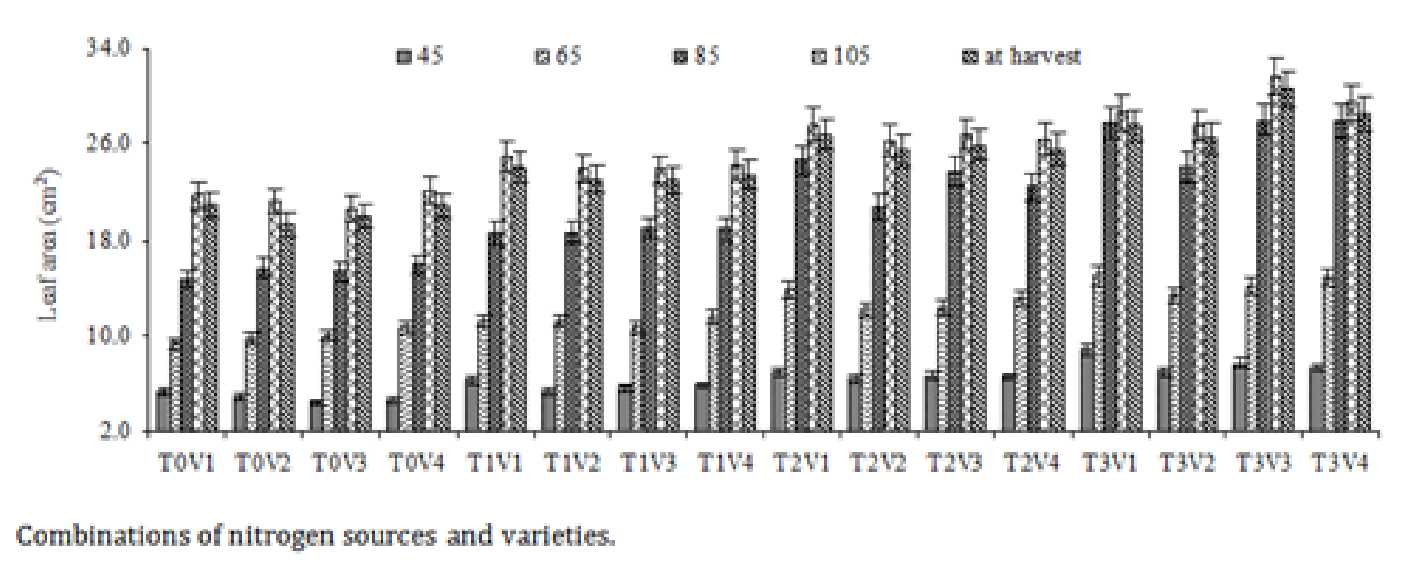

Figure 3 Effect of different

1. nitrogen sources and

2. varieties

3. combinations for leaf area of rice

Here, $\mathrm{V}_{1}=$ Heera, $\mathrm{V}_{2}=\mathrm{SL} 8 \mathrm{H}, \mathrm{V}_{3}=\mathrm{BRRI}$ dhan $58, \mathrm{~V}_{4}=\mathrm{BRRI}$ dhan 29 , and $\mathrm{T}_{0}=$ Control, $\mathrm{T}_{1}=$ Prilled Urea, $\mathrm{T}_{2}=$ Mixed Urea, $\mathrm{T}_{3}=$ USG 


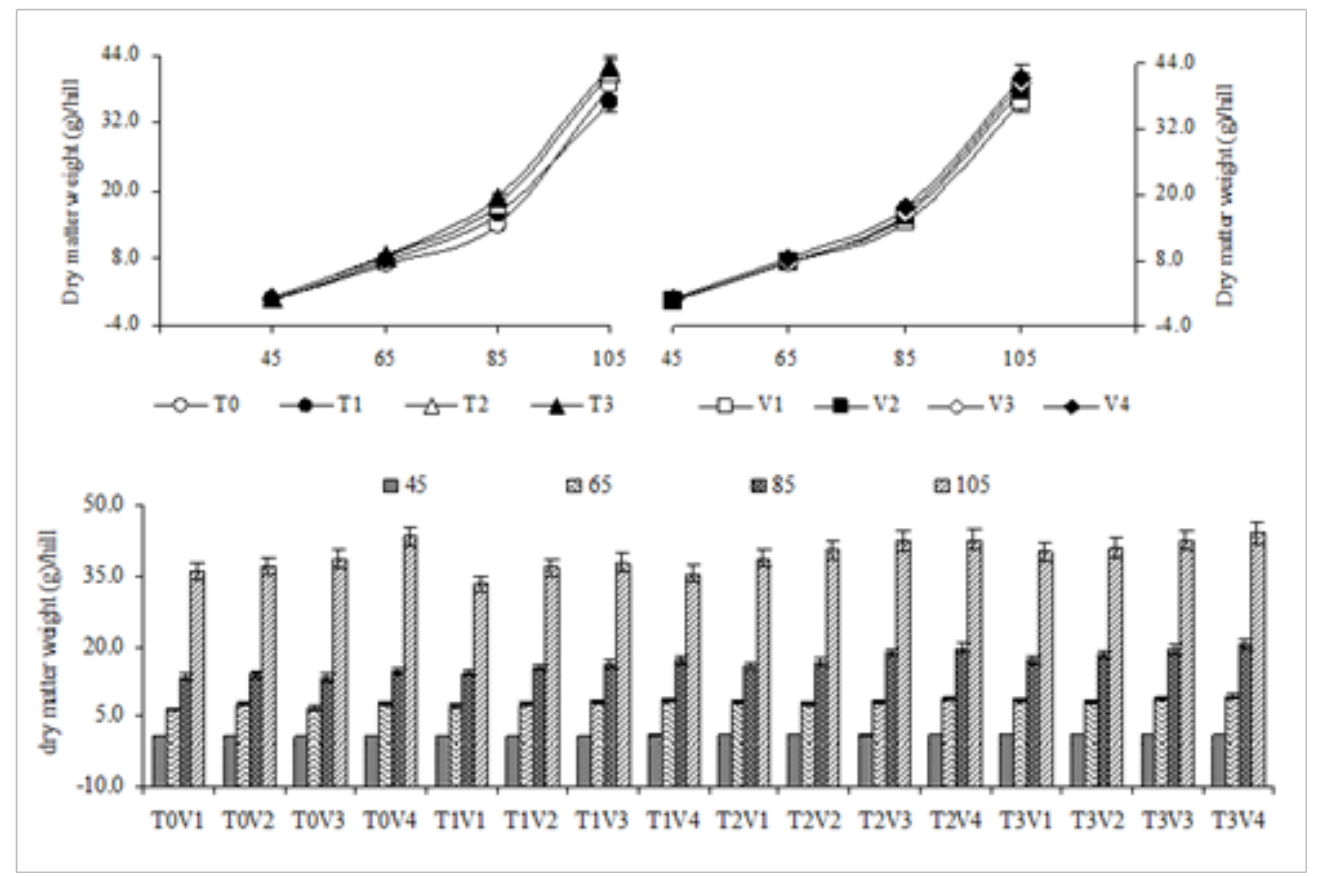

Figure 4 Effect of different

I. nitrogen sources and

2. varieties

3. combinations for dry matter weight of rice

Here, $\mathrm{V}_{1}=$ Heera, $\mathrm{V}_{2}=\mathrm{SL8H}, \mathrm{V}_{3}=\mathrm{BRRI}$ dhan58, $\mathrm{V}_{4}=\mathrm{BRRI}$ dhan29, and $\mathrm{T}_{0}=$ Control, $\mathrm{T}_{1}=$ Prilled Urea, $\mathrm{T}_{2}=$ Mixed Urea, $\mathrm{T}_{3}=\mathrm{USG}$

1000-grain weight (g): The weight of 1000 grains was significantly influenced by the different nitrogen sources, varieties and interaction of these treatments (Table 1). The highest 1000-grains weight found for $\mathrm{T}_{3}(22.7 \mathrm{~g}), \mathrm{V}_{2}(23.1 \mathrm{~g})$ and $\mathrm{T}_{3} \mathrm{~V}_{1}(23.8 \mathrm{~g})$ whereas lowest for $\mathrm{T}_{0}$ $(21.5 \mathrm{~g}), \mathrm{V}_{1}(20.8 \mathrm{~g})$ and $\mathrm{T}_{0} \mathrm{~V}_{4}(20.4 \mathrm{~g})$ (Table 1). The result showed that $\mathrm{V}_{3}$ produced $9.9 \%, 4.2 \%$ and $2.3 \%$ heavier seed than $\mathrm{V}_{1}, \mathrm{~V}_{2}$, and $\mathrm{V}_{3}$ respectively. The result fairly agreed with the findings of Mohaddesi et al., ${ }^{20}$ but Rahman ${ }^{21}$ didn't found any influence.

\section{Spikelet sterility}

Tol Spikelet Sterility: Nitrogen source, varieties and those combinations exerted significant variation on spikelet sterility (\%) (Table 2). Result showed that sources of nitrogen reduced the spikelet sterility significantly. The spikelet sterility was lowest for $\mathrm{T}_{3}(5.0 \%)$, $\mathrm{V}_{4}(7.31 \%)$ and $\mathrm{T}_{3} \mathrm{~V}_{4}(4.1 \%)$ while highest for $\mathrm{T}_{0}(14.9 \%), \mathrm{V}_{2}(11.7 \%)$ and $\mathrm{T}_{0} \mathrm{~V}_{2}(18.1 \%)$ (Table 2). USG, mixed NPK and prilled urea reduced the sterility over control treatment. SL8H showed the highest spikelet sterility compared to other varieties.

Sterility (\%) at the top, middle and bottom portion of panicle: Nitrogen sources, varieties and those combinations showed significant variation for producing the percentage of spikelet sterility at top, middle and bottom portion of panicle (Table 2). In most of the cases, the highest sterility was found at bottom portion and lowest at top portion of panicle whereas middle portion of panicle showed intermediate level of sterility. USG has lowest spikelet sterility in all portions. Highest spikelet sterility was found for Heera for all potions (except bottom portion). In bottom portion SL8H showed the highest spikelet sterility. Hybrid varieties BRRI dhan29 and BRRI dhan58 showed the lower level of spikelet sterility than inbred varieties BRRI dhan 29 and BRRI dhan58. The highest sterility was found at bottom portion and lowest at top portion of panicle for all the combined treatments (Table 2).

\section{Yield characters}

Grain yield: The maximum grain yield obtained for $\mathrm{T}_{3}(8.7 \mathrm{t} / \mathrm{ha}), \mathrm{V}_{1}$ $(8.2 \mathrm{t} / \mathrm{ha})$ and $\mathrm{T}_{3} \mathrm{~V}_{1}(9.3 \mathrm{t} / \mathrm{ha})$. On the other hand, lowest grain yield was for $\mathrm{T}_{0}(6.1 \mathrm{t} / \mathrm{ha}), \mathrm{V}_{2}(6.8 \mathrm{t} / \mathrm{ha})$ and $\mathrm{T}_{0} \mathrm{~V}_{4}(5.9 \mathrm{t} / \mathrm{ha})$ (Table 3$)$. Improvement of yield component such as number of effective tillers/hill and number of grains/panicle in these treatments ultimately resulted in high yield of grains. BRRI dhan 29 showed its superiority in producing highest grain yield which was $17.0 \%, 10.2 \%$ and $7.9 \%$ higher than BRRI dhan58, SL8H and Heera, respectively. The results related with the findings of Xie et al., ${ }^{22,23}$ Sumit et al. ${ }^{24}$ and Meena et al. ${ }^{9}$ who observed yield variations among hybrid and high yielding varieties.

Straw yield: Straw yield varied significantly with the different nitrogen sources, varieties and combination (Table 3 ). Straw yield was highest for $\mathrm{T}_{3}(9.7 \mathrm{t} / \mathrm{ha}), \mathrm{V}_{1}(8.9 \mathrm{t} / \mathrm{ha})$ and $\mathrm{T}_{3} \mathrm{~V}_{1}(9.9 \mathrm{t} / \mathrm{ha})$ while lowest for $\mathrm{T}_{0}(6.2 \mathrm{t} / \mathrm{ha}), \mathrm{V}_{2}(7.7 \mathrm{t} / \mathrm{ha})$ and $\mathrm{T}_{0} \mathrm{~V}_{2}(5.8 \mathrm{t} / \mathrm{ha})$ (Table 3$)$. Elbadry 
et al., ${ }^{25}$ Meena et al., ${ }^{9}$ and El-Rewainy ${ }^{26}$ observed similar view on straw yield due to nitrogen application. The differences in straw yield among the varieties might be attributed to the genetic makeup of the varieties. Patel, ${ }^{27}$ reported variable straw yield among the varieties.

Biological yield: Biological yield differed significantly due to the different sources of nitrogen, varieties and those combinations. $\mathrm{T}_{3}$ produced the highest biological yield $(18.3 \mathrm{t} / \mathrm{ha})$ and lowest was recorded from $T_{0}(12.3 \mathrm{t} / \mathrm{ha}$ ) (Table 3$)$. The result agreed with the findings of Ahmed et al., ${ }^{3}$ who observed the significant effect of nitrogen on biological yield of rice. Biological yield was ranges from 14.6-17.1t/ha (Table 3). The highest and lowest biological yield was obtained from BRRI dhan 29 and BRRI dhan58, respectively. The results showed that the interaction between $\mathrm{T}_{3} \mathrm{~V}_{1}$ gave the highest biological yield (19.3t/ha) and lowest from $\mathrm{T}_{0} \mathrm{~V}_{2}$ (11.68t/ha) (Table 3).

Harvest index: No significant difference was observed for harvest index due to varietal differences but harvest index varied due to the variation of the treatments and combination of the nitrogen sources and varieties. Maximum harvest index was found for $\mathrm{T}_{3}(49.3 \%), \mathrm{V}_{4}$ $(48.6 \%)$ and $\mathrm{T}_{3} \mathrm{~V}_{4}(50.3 \%)$ while lowest for $\mathrm{T}_{0}(47.1 \%), \mathrm{V}_{3}(47.2 \%)$ and $\mathrm{T}_{3} \mathrm{~V}_{3}(43.7 \%)$ (Table 3$)$.

Table I Effect of nitrogen sources, varieties and combination of these two treatments on yield contributing characteristics of rice

\begin{tabular}{|c|c|c|c|c|c|c|c|c|c|c|}
\hline \multirow{2}{*}{ Treatments } & \multicolumn{4}{|c|}{ Number of tillers/hill } & \multicolumn{6}{|c|}{ Number of grains/panicle } \\
\hline & \multicolumn{2}{|r|}{ Effective tillers } & \multicolumn{2}{|c|}{ Non-effective } & \multicolumn{2}{|c|}{ Filled } & \multicolumn{2}{|c|}{ Unfilled } & \multicolumn{2}{|c|}{ 1000- seed Weight (G) } \\
\hline \multicolumn{11}{|c|}{ Nitrogen sources } \\
\hline T0 & 9.3 & $\mathrm{c}$ & 1.5 & a & 69.5 & $\mathrm{c}$ & 14.5 & $\mathrm{a}$ & 21.5 & d \\
\hline T1 & 13.9 & $\mathrm{~b}$ & 1.3 & $\mathrm{~b}$ & 89.6 & $\mathrm{~b}$ & 11.6 & $\mathrm{~b}$ & 21.9 & c \\
\hline $\mathrm{T} 2$ & 14.2 & $\mathrm{~b}$ & 1.2 & $\mathrm{~b}$ & 90.8 & $\mathrm{~b}$ & 10.8 & $\mathrm{~b}$ & 22.3 & $\mathrm{~b}$ \\
\hline T3 & 15.8 & $\mathrm{a}$ & 0.6 & $\mathrm{c}$ & 102.1 & $\mathrm{a}$ & 6.7 & $\mathrm{c}$ & 22.7 & $\mathrm{a}$ \\
\hline \multicolumn{11}{|l|}{ Varieties } \\
\hline V1 & 12.2 & $\mathrm{c}$ & 1.2 & a & 84.8 & $\mathrm{bc}$ & 7.5 & d & 22.5 & $\mathrm{~b}$ \\
\hline V2 & 13.3 & $\mathrm{~b}$ & 1.2 & $\mathrm{a}$ & 82.1 & $\mathrm{c}$ & 9.5 & $\mathrm{c}$ & 23.1 & $\mathrm{a}$ \\
\hline V3 & 13.6 & $\mathrm{~b}$ & 1.1 & a & 86.3 & $\mathrm{~b}$ & 12.8 & $\mathrm{~b}$ & 22.1 & $\mathrm{~b}$ \\
\hline V4 & 14.3 & $\mathrm{a}$ & 1.2 & a & 98.8 & $\mathrm{a}$ & 13.7 & $\mathrm{a}$ & 20.8 & $\mathrm{c}$ \\
\hline \multicolumn{11}{|c|}{ Combinations } \\
\hline T0V1 & 8.6 & $\mathrm{j}$ & 1.6 & $\mathrm{~b}$ & 73.4 & $\mathrm{fg}$ & 8.9 & ef & 21.8 & $d-f$ \\
\hline T0V2 & 9 & ij & 1.7 & a & 63.2 & $\mathrm{~h}$ & 13.1 & $\mathrm{~cd}$ & 22.5 & $b-d$ \\
\hline T0V3 & 9.6 & ij & 1.5 & $\mathrm{~b}$ & 66.7 & $\mathrm{gh}$ & 16.7 & $\mathrm{~b}$ & 21.4 & e-g \\
\hline T0V4 & 9.9 & $\mathrm{i}$ & 1.4 & $\mathrm{bc}$ & 74.9 & $f$ & 19.2 & $\mathrm{a}$ & 20.4 & g \\
\hline T1V1 & 12.8 & $\mathrm{~h}$ & 1.3 & $\mathrm{~cd}$ & 85.4 & $\mathrm{e}$ & 8 & ef & 21.7 & $d-f$ \\
\hline T1V2 & 13.8 & fg & 1.3 & $\mathrm{~cd}$ & 83.1 & e & 9.6 & $\mathrm{e}$ & 23 & $a-c$ \\
\hline T1V3 & 14.1 & d-g & 1.2 & $d$ & 87.8 & $\mathrm{e}$ & 14.4 & $\mathrm{c}$ & 22.2 & c-e \\
\hline T1V4 & 15 & c-e & 1.4 & $\mathrm{bc}$ & 102.1 & $\mathrm{bc}$ & 14.3 & $\mathrm{c}$ & 20.8 & $\mathrm{fg}$ \\
\hline $\mathrm{T} 2 \mathrm{~V} 1$ & 13.2 & gh & 1.3 & $\mathrm{~cd}$ & 85.1 & $\mathrm{e}$ & 7.8 & $e-g$ & 22.8 & b-d \\
\hline $\mathrm{T} 2 \mathrm{~V} 2$ & 14.1 & e-g & 1.2 & $\mathrm{~d}$ & 85.6 & $\mathrm{e}$ & 9.3 & ef & 23.2 & $\mathrm{a}-\mathrm{c}$ \\
\hline $\mathrm{T} 2 \mathrm{~V} 3$ & 14.5 & d-e & 1.2 & $\mathrm{~d}$ & 89.3 & de & 12.2 & $\mathrm{~d}$ & 22.2 & c-e \\
\hline $\mathrm{T} 2 \mathrm{~V} 4$ & 15.2 & b-d & 1.3 & $\mathrm{~cd}$ & 103.2 & $\mathrm{~b}$ & 14 & $\mathrm{~cd}$ & 20.9 & $\mathrm{fg}$ \\
\hline T3V1 & 14.2 & d-g & 0.6 & $\mathrm{e}$ & 95.1 & $\mathrm{~cd}$ & 5.5 & $\mathrm{~h}$ & 23.8 & $\mathrm{a}$ \\
\hline T3V2 & 16.1 & $a b$ & 0.5 & e & 96.5 & b-d & 5.9 & gh & 23.5 & $a b$ \\
\hline T3V3 & 16 & $a b c$ & 0.7 & e & 101.5 & $\mathrm{bc}$ & 7.9 & ef & 22.5 & b-d \\
\hline T3V4 & 16.9 & $\mathrm{a}$ & 0.7 & e & 115.1 & $\mathrm{a}$ & 7.5 & $\mathrm{fg}$ & 20.9 & $\mathrm{fg}$ \\
\hline CV\% & 4.3 & & 7.9 & & 4.6 & & 9.8 & & 2.5 & \\
\hline
\end{tabular}

Values in column having different letter are significantly different and same letter are not significantly different at 0.05 level of probability by DMRT. 
Table 2 Effect of nitrogen sources, varieties and those combinations on spikelet sterility of boro rice

\begin{tabular}{|c|c|c|c|c|c|c|c|c|}
\hline \multirow{2}{*}{ Treatments } & \multicolumn{8}{|c|}{ Spikelet sterility (\%) of panicle At } \\
\hline & \multicolumn{2}{|l|}{ Total } & \multicolumn{2}{|c|}{ Top portion } & \multicolumn{2}{|c|}{ Middle portion } & \multicolumn{2}{|c|}{ Bottom portion } \\
\hline \multicolumn{9}{|c|}{ Nitrogen sources } \\
\hline T0 & 14.9 & a & 3.4 & a & 5.1 & a & 6.3 & $\mathrm{a}$ \\
\hline $\mathrm{T} 1$ & 10.3 & $\mathrm{~b}$ & 2.3 & $\mathrm{~b}$ & 3.7 & $\mathrm{~b}$ & 4.3 & $\mathrm{~b}$ \\
\hline $\mathrm{T} 2$ & 9.6 & $\mathrm{c}$ & 2.1 & $\mathrm{~b}$ & 3.2 & $\mathrm{c}$ & 4.2 & $\mathrm{~b}$ \\
\hline $\mathrm{T} 3$ & 5 & d & 1.3 & $\mathrm{c}$ & 1.2 & d & 2.6 & $\mathrm{c}$ \\
\hline \multicolumn{9}{|l|}{ Varieties } \\
\hline V1 & 11.1 & $\mathrm{~b}$ & 3 & a & 3.8 & a & 4.3 & $\mathrm{~b}$ \\
\hline $\mathrm{V} 2$ & 11.7 & a & 2.3 & $\mathrm{~b}$ & 3.4 & $\mathrm{~b}$ & 6 & $\mathrm{a}$ \\
\hline V3 & 9.7 & $\mathrm{c}$ & 2.1 & $\mathrm{~b}$ & 3.3 & $\mathrm{~b}$ & 4.3 & $\mathrm{~b}$ \\
\hline V4 & 7.3 & d & 1.8 & $\mathrm{c}$ & 2.7 & $\mathrm{c}$ & 2.9 & $\mathrm{c}$ \\
\hline \multicolumn{9}{|c|}{ Combinations } \\
\hline T0V1 & 17 & $\mathrm{a}$ & 5.1 & $\mathrm{a}$ & 6 & $\mathrm{a}$ & 8.3 & $\mathrm{a}$ \\
\hline T0V2 & 18.1 & $\mathrm{~b}$ & 3.1 & $\mathrm{~b}$ & 5.5 & $\mathrm{~b}$ & 6.9 & $\mathrm{~b}$ \\
\hline T0V3 & 14.7 & $\mathrm{c}$ & 3.4 & $\mathrm{~b}$ & 5.1 & $\mathrm{c}$ & 6.1 & $\mathrm{c}$ \\
\hline T0V4 & 10 & $\mathrm{f}$ & 2.3 & de & 3.8 & $\mathrm{e}$ & 4.1 & $\mathrm{e}$ \\
\hline T1V1 & 11.8 & d & 3 & $\mathrm{~b}$ & 4.1 & d & 5.4 & d \\
\hline T1V2 & 11.9 & d & 2.3 & de & 4.1 & de & 4.5 & $\mathrm{e}$ \\
\hline T1V3 & 9.6 & fg & 2.1 & ef & 3.2 & $\mathrm{f}$ & 4.5 & $\mathrm{e}$ \\
\hline T1V4 & 7.8 & $\mathrm{~h}$ & 1.7 & $\mathrm{fg}$ & 3.3 & $\mathrm{f}$ & 2.9 & $f$ \\
\hline $\mathrm{T} 2 \mathrm{~V} 1$ & 10.6 & $\mathrm{e}$ & 2.7 & $\mathrm{c}$ & 4 & de & 5.4 & $d$ \\
\hline $\mathrm{T} 2 \mathrm{~V} 2$ & 11.3 & d & 2.4 & $\mathrm{~cd}$ & 2.9 & $\mathrm{~g}$ & 4.1 & $\mathrm{e}$ \\
\hline $\mathrm{T} 2 \mathrm{~V} 3$ & 9.4 & g & 1.8 & $\mathrm{fg}$ & 3.3 & f & 4.1 & $\mathrm{e}$ \\
\hline $\mathrm{T} 2 \mathrm{~V} 4$ & 7.1 & $\mathrm{i}$ & 1.6 & g & 2.5 & $\mathrm{~h}$ & 2.9 & $f$ \\
\hline T3V1 & 4.4 & $\mathrm{jk}$ & 1.1 & $\mathrm{~h}$ & 1.1 & $\mathrm{i}$ & 1.8 & $\mathrm{~h}$ \\
\hline $\mathrm{T} 3 \mathrm{~V} 2$ & 6.7 & $\mathrm{i}$ & 1.2 & $\mathrm{~h}$ & 1.1 & $\mathrm{i}$ & 4.4 & e \\
\hline T3V3 & 4.9 & $\mathrm{jk}$ & 1.2 & $\mathrm{~h}$ & 1.4 & $\mathrm{i}$ & 2.4 & g \\
\hline $\mathrm{T} 3 \mathrm{~V} 4$ & 4.1 & $\mathrm{k}$ & 1.6 & $\mathrm{~g}$ & 1.2 & $\mathrm{i}$ & 1.8 & $\mathrm{~h}$ \\
\hline CV (\%) & 8.5 & & 8.4 & & 11.9 & & 9.4 & \\
\hline
\end{tabular}

Values in column having different letter are significantly different and same letter are not significantly different at 0.05 level of probability by DMRT. 
Table 3 Effect of nitrogen sources, varieties and those combinations on yield and harvest index of boro rice

\begin{tabular}{|c|c|c|c|c|c|c|c|c|}
\hline \multirow{2}{*}{ Treatments } & \multicolumn{6}{|c|}{ Yield (t/ha) } & \multirow{2}{*}{\multicolumn{2}{|c|}{ Harvest index (\%) }} \\
\hline & \multicolumn{2}{|c|}{ Grain } & \multicolumn{2}{|c|}{ Straw } & \multicolumn{2}{|c|}{ Biological } & & \\
\hline T0 & 6.1 & $\mathrm{~d}$ & 6.2 & d & 12.3 & $\mathrm{~d}$ & 47.1 & $\mathrm{c}$ \\
\hline $\mathrm{T} 1$ & 7.1 & $\mathrm{c}$ & 7.9 & c & 15.1 & $\mathrm{c}$ & 47.3 & $\mathrm{bc}$ \\
\hline $\mathrm{T} 2$ & 8.2 & $\mathrm{~b}$ & 8.6 & $\mathrm{~b}$ & 16.8 & $\mathrm{~b}$ & 48.8 & $a b$ \\
\hline $\mathrm{T} 3$ & 8.6 & $\mathrm{a}$ & 9.7 & $\mathrm{a}$ & 18.3 & $\mathrm{a}$ & 49.3 & $\mathrm{a}$ \\
\hline \multicolumn{9}{|l|}{ Varieties } \\
\hline V1 & 7.6 & $\mathrm{~b}$ & 8 & $\mathrm{~b}$ & 15.6 & $\mathrm{~b}$ & 48.2 & NS \\
\hline V2 & 7.4 & $\mathrm{~b}$ & 7.8 & $\mathrm{~b}$ & 15.2 & $\mathrm{~b}$ & 48.5 & NS \\
\hline V3 & 6.8 & $\mathrm{c}$ & 7.7 & $\mathrm{~b}$ & 14.6 & $\mathrm{c}$ & 47.2 & NS \\
\hline V4 & 8.2 & $\mathrm{a}$ & 8.9 & $\mathrm{a}$ & 17.1 & $\mathrm{a}$ & 48.6 & NS \\
\hline \multicolumn{9}{|l|}{ Combinations } \\
\hline T0V1 & 5.9 & g & 6.3 & gh & 12.3 & gh & 48.2 & $\mathrm{ab}$ \\
\hline T0V2 & 5.9 & g & 6 & $\mathrm{~h}$ & 11.9 & $\mathrm{~h}$ & 48 & $\mathrm{ab}$ \\
\hline T0V3 & 5.9 & g & 5.8 & $\mathrm{~h}$ & 11.7 & $\mathrm{~h}$ & 43.7 & $\mathrm{c}$ \\
\hline T0V4 & 6.6 & $\mathrm{fg}$ & 6.8 & $\mathrm{fg}$ & 13.4 & $\mathrm{fg}$ & 48.4 & $\mathrm{ab}$ \\
\hline T1V1 & 7.2 & ef & 7.5 & ef & 14.6 & ef & 49 & $a b$ \\
\hline T1V2 & 6.7 & e-g & 7.4 & ef & 14.1 & ef & 47.2 & $a-c$ \\
\hline T1V3 & 6.6 & $\mathrm{fg}$ & 7.6 & ef & 14.1 & ef & 46.5 & $\mathrm{bc}$ \\
\hline T1V4 & 8.1 & b-d & 9.3 & $a b$ & 17.4 & $b-d$ & 46.6 & $a-c$ \\
\hline $\mathrm{T} 2 \mathrm{~V} 1$ & 8.2 & $\mathrm{bc}$ & 8.7 & $\mathrm{bc}$ & 16.9 & $\mathrm{~d}$ & 48.7 & $a b$ \\
\hline $\mathrm{T} 2 \mathrm{~V} 2$ & 8.2 & $\mathrm{bc}$ & 8.4 & $\mathrm{~cd}$ & 16.6 & $\mathrm{~d}$ & 49.6 & $a b$ \\
\hline $\mathrm{T} 2 \mathrm{~V} 3$ & 7.4 & $d-f$ & 7.9 & de & 15.2 & ef & 48.3 & $\mathrm{ab}$ \\
\hline $\mathrm{T} 2 \mathrm{~V} 4$ & 8.9 & $a b$ & 9.4 & $a b$ & 18.3 & $a-c$ & 48.7 & $a b$ \\
\hline T3V1 & 9 & $a b$ & 9.7 & $\mathrm{a}$ & 18.7 & $a b$ & 48.4 & $a b$ \\
\hline T3V2 & 8.8 & $a b$ & 9.5 & $a b$ & 18.3 & $a-c$ & 49.4 & $a b$ \\
\hline T3V3 & 7.5 & c-e & 9.6 & $\mathrm{a}$ & 17.2 & $\mathrm{~cd}$ & 49 & $a b$ \\
\hline T3V4 & 9.3 & $\mathrm{a}$ & 9.9 & $\mathrm{a}$ & 19.3 & $\mathrm{a}$ & 50.3 & $\mathrm{a}$ \\
\hline CV (\%) & 7.7 & & 8.8 & & 7.7 & & 10.9 & \\
\hline
\end{tabular}

Values in column having different letter are significantly different and same letter are not significantly different at 0.05 level of probability by DMRT.

NS, non significant.

\section{Conclusion}

Results of the present study for suggest using of USG, BRRI dhan29 and those treatments combinations. Both nitrogen source USG and BRRI dhan 29 variety are superior than others for maintaining minimum level of spikelet sterility thus leading to the maximum yield. The study also suggests that hybrid varieties are better than inbreed varieties for producing more fertile spikelets of rice.

\section{Acknowledgements}

The authors are grateful to the Department of Agronomy, Sher-eBangla Agricultural University, Dhaka, Bangladesh for supporting all of the materials for this research work. Authors are also thankful to the staff and farm members of the same department.

\section{Conflict of interest}

The author declares no conflict of interest.

\section{References}

1. Yoshida S. Fundamentals of Rice Crop Science lnt. Rice Res. Inst. Manila, Philippines; 1991

2. BRRI. Annual Report for 1990. Joydebpur, Gazipur: Bangladesh Rice Research Institute; 1990. p. 61-73. 
3. Ahmed M, Islam M, Paul SK. Effect of nitrogen on yield and other plant characters of local T. Aman Rice Var Jatai. Research Journal of Agriculture and Biological Sciences. 2005;1(2):158-161.

4. Iqbal. Detection of suitable soils for Zero-Till wheat sowing in Gujranwala using GITs. MS Thesis. Pakistan: National University of Sciences and Technology; 2011.

5. Wani AR, Hasan B, Bali AS. Relative efficiency of some modified urea materials in transplanted rice under temperate conditions of Kashmir. Oryza. 1999;36(4):382-383.

6. Gunawardena TA, Fukai S, Blarney FPC. Low temperature induced spikelet sterility in rice. I. Nitrogen fertilization and sensitive reproductive period Australian. J Agril Res. 2003;54(10):937-946.

7. BRRI. Adunik Dhaner Chash (in Bangla). 17th ed. Joydebpur, Gazipur: Bangladesh Rice Research Institute; 2013. p. 17-33.

8. Gomez AK, Gomez AA. Statistical Procedures for Agricultural Research. 2nd ed. New York: John Wiley and Sons, Inc; 1984. p. 8-20.

9. Meena SL, Sundera S, Shivay YS. Response to hybrid rice (Oryza sativa) to nitrogen and potassium application in sandy clay-loam soils. Indian $J$ Agric Sci. 2003;73(1):8-11.

10. Sahrawat KL, Diatta S, Singh BN. Nitrogen responsiveness of lowland rice varieties under irrigated condition in West Africa. Intl Rice Res Notes. 1999;24(2):30.

11. Thakur RB. Performance of summer rice (Oryza sativa) to varying levels of nitrogen. Indian J Agron. 1993;38(2):187-190.

12. Rahman MA, Hossain MS, Chowdhury IF, et al. Variability study of advanced fine rice with correlation, path co-efficient analysis of yield and yield contributing characters. International Journal of Applied Sciences and Biotechnology. 2014;2(3):364-370.

13. Rahman MA, Md Sarowar Hossain, Imtiaz Faruk Chowdhury, et al. Performance of yield and quality in advanced lines of fine rice (Oryza sativa). Trends in Biotechnology \& Biological Sciences. 2014;1(1):9-18.

14. Sikder RK, Rahman MA, Asif MI, et al. Genetic variability, distance and traits interrelationship analysis of nerica and inpari rice varieties. Scientia Agriculturae. 2015;10(1):44-48.

15. Zaman H, Masum SM, Ali $\mathrm{MH}$, et al. Tiller production and yield improvement of T. aman rice varieties through wider spacing. MiddleEast Journal of Scientific Research. 2015;23(6):1114-1121.

16. BINA (Bangladesh Institute of Nuclear Agriculture). Technical report on hybrid rice Alok 6201. Div Agron, Mymensingh: Bangladesh Inst Nuc Agric; 1998. p. 1-3.

17. Om H, Dhiman SD, Nandal DP, et al. Effect of method of nursery raising and nitrogen on growth and yield of hybrid rice (Oryza sativa). Indian J Agron. 1998;43(1):68-70.
18. Bhowmick N, Nayak RL. Response of hybrid rice (Oryza sativa) varieties to nitrogen, phosphorus and potassium fertilizers during dry (boro) season in West Bengal. Indian J Agron. 2000;45(2):323-326.

19. BRRI (Bangladesh Rice Research Institute). Annual Report for 2005 2006 Bangladesh Rice Res. Inst, Joydebpur, Gazipur, Bangladesh; 2006. p. 63-67.

20. Mohaddesi A, Abbasian A, Bakhshipour S, et al. Effect of different levels of nitrogen and plant spacing on yield, yield components and physiological indices in high-yield rice (Number 843). American-Eurasian Journal of Agricultural \& Environmental Sciences. 2011;10(5):893-900.

21. Rahman MA. Effect of levels of urea super granules and depth of placement on the growth and yield of transplant aman rice. MS (Ag) Thesis, Department of Agronomy, Mymensingh: Bangladesh Agricultural University; 2003. 100 p.

22. Xie W, Wang G, Zhang Q. Potential production simulation and optimal nutrient management of two hybrid rice varieties in Jinhua, Zhejiang Province. J Zhejiang Univ Sci. 2007;8(7):486-492.

23. Xie W, Wang G, Zhang Q, et al. Effects of nitrogen fertilization strategies on nitrogen use efficiency in physiology, recovery and agronomy and redistribution of dry matter accumulation and nitrogen accumulation in two typical rice cultivars in Zhejiang, China. J Zhejiang Univ Sci. 2007;8(3):208-216.

24. Sumit C, Pyare L, Singh AP, et al. Agronomic and morpho-physiological analysis of growth and productivity in hybrid rice (Oryza sativa L). Annals Biol. 2004;20(2):233-238.

25. Elbadry M, Gamal-Eldin H, Elbanna K. Effect of Rhodobacter capsulatus inoculation in combination with graded levels of nitrogen fertilizer on growth and yield of rice in pots and lysimeter experiments. World $J$ Microbiol Biotech. 2004;15(3):393-395.

26. El-Rewainy IMO. The effect of different nitrogen fertilizer source on yield and some agricultural characters in rice. $\mathrm{PhD}$, Thesis, Fac Agric Shebin El-Kom, Egypt: Menofia Univ; 2002.

27. Patel JR. Effect of water regime, variety blue green algae on rice (Oryza sativa) hybrids. Indian J Agron. 2000;45(1):103-106.

28. Hari OM, Katyal SK, Dhiman SD. Response of two nee hybrids to graded levels of nitrogen. Indian J Agric Sci. 2000;70(3):140-142. 